\title{
The Walking Dead o la insoportable contemporaneidad del ser
}

\author{
ANTONIO BERNÁRDEZ SOBREIRA
}

Antonio Bernárdez Sobreira (Vigo, 1970) es licenciado en Xeografía e Historia por la Universidad de Santiago de Compostela (1993), en la especialidad de Historia Contemporánea. Investigador en Historia Rural, ha publicado estudios sobre las políticas agrarias (Planificación agraria na Galicia da Autarquía, 1999) así como sobre la movilización social del campesinado (A penetración do sindicalismo no rural galego de anteguerra en 2006 y Labrando na Rebelión en 2007, ambos en colaboración con Isidro Román Lago), además de diversos artículos y comunicaciones. Desde 1998 ejerce la docencia como profesor de enseñanza secundaria, especializándose desde 2007 en la enseñanza de adultos, destacando cuatro cursos (2007-2011) en centros penitenciarios.

\section{RESUMEN}

Este artículo pretende ser una reflexión desde un punto de vista historiográfico del exitoso cómic de Robert Kirkman. Proponemos una caracterización de la obra como profundamente política e imbricada en el ecosistema ideológico y cultural norteamericano. A partir de tres apartados caracterizaremos The Walking Dead como una negra utopía, un contrapaisaje donde podemos reconocer importantes aspectos relacionados con el desarrollo histórico de los USA, su construcción ideológica así como la crisis del ideal optimista de progreso vigente desde la Ilustración.

\begin{abstract}
This article tries to be a reflection from an historiographic point of view about Robert Kirkman's successful cómic. We will propose a characterization of this comic as deeply political and overlapped in the ideological and cultural North American ecosystem. In three parts we will characterize The Walking Dead as a black Utopia, a landscape where we can recognize significative facts linked to the historical development of the USA, his ideological building as well as the crisis of the optimist ideology of progress in force from the Illustration.
\end{abstract}

CuCo, Cuadernos de cómic número 1. Septiembre de 2013

CuCoEstudio 
Adoro The Walking Dead ${ }^{1}$ hasta el punto que alguna vez he llegado a comentar que se trata de la mejor serie regular que podemos encontrar en este momento en el mercado (obviamente es un comentario hiperbólico). Kirkman no posee la erudición de Alan Moore (ni su compromiso antitotalitario de pura vena hippie), el gamberrismo libertario y psicotrópico de Grant Morrison o incluso el salvajismo proletario de Mark Millar. Pudiendo ser Víctor Hugo ha optado por Alejandro Dumas, y como él ha sido capaz de recoger el legado de su época, ${ }^{2}$ toda una tradición narrativa e incluso ideológica para transformarla en el folletín total: coral, denso y por supuesto siempre imprevisible (incluso contradictorio).

Como Dumas, Kirkman no busca la originalidad y carece de un plan preconcebido (él mismo lo reconoce cuando es preguntado por ello). ${ }^{3}$ El valor de su relato no estriba en la causa sino en el desarrollo de la acción y de los personajes ${ }^{4}$ pero tampoco en ello va a ser genuino, ya que se inscribe en toda la tradición narrativa que configuró el fenómeno zombi desde Romero. En este sentido Kirkman supo leer el contexto cultural de la Norteamérica posterior al 11 de septiembre que entre otros experimentó un auténtico boom de la narrativa del muerto viviente (o caminante) y que por obra y gracia de la globalización se transmitió de forma vírica a escala mundial: ${ }^{5} 28$ días

\footnotetext{
${ }^{1}$ Los muertos vivientes en la edición española de Editorial Planeta De Agostini. A partir de ahora cuando nos refiramos directamente a la serie gráfica utilizaremos LMV.

2 Para Pierre Blanc, LMV sería definible como un western apocalíptico (e incluso crepuscular) que bebería del legado de la Gran Novela Americana como una historia de pioneros y robinsones. Vid. Blanc, P. "Pioneros y robinsones", en VV. AA. The Walking Dead. Apocalipsis zombi ya. Madrid, Errata naturae, 2012, p. 174.

3 "Y siguen caminando y caminando y caminando... Kirkman habla de Los muertos vivientes", entrevista publicada por Entrecomics, 2 de octubre de 2006, http://www.entrecomics.com/?p=683. Una visión de conjunto de Kirkman y su obra se puede leer en SERRADILla, E. ROBERT KIRKMAN: De The Walking Dead a Invencible. Palma de Mallorca, Pretextos Dolmen, 2011.
}

4 BEISECKER, D. "Me muero por hacer de zombi empanado", en VV. AA.. The Walking Dead. Apocalipsis zombi ya. Madrid, Errata naturae, 2012, p. 23.

${ }^{5}$ F. DíAz, L. The Walking Dead. El libro. Madrid, Alberto Santos Editor, pp. 37-44. Es muy interesante al respecto el artículo de FERRERO, A. y ROAS, S. "El zombi como metáfora (contra) cultural" en Nómadas. Revista Crítica de Ciencias Sociales y Jurídicas, n. ${ }^{o}$ 32, 2011 (www.ucm.es/info/nomadas/32).

CuCo, Cuadernos de cómic número 1. Septiembre de 2013 
después con su secuela (Danny Boyle, 2002 y Juan Carlos Fresnadillo, 2007), Resident Evil (Paul Anderson, 2002), Dawn of the Dead (Zack Snyder, 2004)...

El objetivo inicial de Kirkman era escribir una historia ambientada en el espacio y titulada de forma rimbombante Dead Planet, ${ }^{6}$ pero una vez desechada eligió profundizar en el modelo establecido por George A. Romero, iniciando un éxito editorial que luego consolidaría con la serie de televisión. ${ }^{7}$ Algunas de las claves de ese éxito han sido ya señaladas por la crítica, por ejemplo un desarrollo narrativo minucioso que sin embargo deja en la tiniebla o el silencio el pasado. ${ }^{8}$ Por otro lado, una característica esencial del tema de los zombis como son los conflictos entre supervivientes da a Kirkman la excusa para pintar los caminantes más como un elemento del paisaje que como protagonistas, de manera que prima en todo momento la descripción de la imposibilidad de cooperación entre los vivos ("discusiones entre personajes, juegos de poder y territorialidad, decisiones, desavenencias, pactos") frente a la propia circunstancia de los muertos, algo que por otro lado profundiza una vez más en el legado de Romero. ${ }^{9}$ En este sentido Kirkman es capaz de explorar lo que Mike Davis define como "las potencias críticas de lo ordinario, desechable y feo" $"$ o lo que es lo mismo el tremendo potencial de lo cotidiano como "verdadero espacio de conflicto para el ser humano". ${ }^{11}$

\footnotetext{
${ }^{6}$ GArcíA, S. "The Walking Dead, el cómic: un valle de lágrimas", en VV. AA. The Walking Dead. Apocalipsis zombi ya. Madrid, Errata naturae, 2012, p. 124.

${ }^{7}$ El primer número USA de LMV tiene fecha de octubre de 2003 y la serie de AMC fue presentada en sociedad en la comicon de San Diego de julio de 2010. Vid. F. DíAZ, L. Op. cit., pp. 7 y 49.

${ }^{8}$ GARCÍA, S. Op.Cit., p. 129.

${ }^{9}$ La cita literal está tomada de FERNÁNDEZ GonZAlo, J. Filosofía zombi. Barcelona, Anagrama, 2011, p. 20.

${ }^{10}$ DAVIS, M. Ciudades muertas. Ecología, catástrofe y revuelta. Madrid, Traficantes de Sueños, 2007, p. 56.

${ }^{11}$ FERNÁNDEZ GonZALO, J. “AApocalipsis o apoca-e-lipsis? Pantalla y emociones en The Walking Dead”, en VV. AA. The Walking Dead. Apocalipsis zombi ya. Madrid, Errata naturae, 2012, pp. 68-69.
}

CuCo, Cuadernos de cómic número 1. Septiembre de 2013 
En palabras de Fernández Gonzalo "las actitudes ante lo cotidiano muestran los rincones oscuros de la naturaleza humana en todo su doloroso esplendor". ${ }^{12}$

El tratamiento de los supervivientes ha llevado a afirmar que los zombis de Kirkman "están despolitizados y se los ha vaciado de significación metafórica o simbólica", y forman parte (como ya dijimos) de un particular mundo feliz (del que hablaremos luego) y en el que "los elementos predominantes (...) son el vacío y el estatismo". ${ }^{13}$ Esto viene a cuento en la medida en que en el zombi (el monstruo en general) como metáfora tienen tanta importancia las cualidades del ser monstruoso como la propia narración. ${ }^{14}$ Por el contrario, los caminantes de Kirkman no experimentan ningún desarrollo más allá de las reflexiones morales o actos violentos que provocan entre los supervivientes. Sin embargo, a mi modo de ver son un espejo en el que mirarse en el momento de desmoronamiento del viejo orden social y eso los dota de un innegable sentido político: "el monstruo no es un accidente, representa la sempiterna posibilidad de destrucción del orden natural de la autoridad en todos los ámbitos". ${ }^{15}$ Lo que habría que analizar es si ese sentido político de lo monstruoso forma parte de un objetivo consciente del autor o puede ser establecido a posteriori por el lector, porque a mi modo de ver LMV es una obra profundamente política en su conjunto y sobre esta cuestión versará buena parte de este texto.

Cuando Romero estrenó en 1968 The Night of the Living Dead fue interpretada como una metáfora de la Norteamérica de los sesenta, con su racismo, su lucha por los derechos civiles y su guerra en Indochina, algo que el director afirma que no estaba en

\footnotetext{
${ }^{12}$ Ibíd., p. 67.

13 Round, J. "El horror de la humanidad", en VV. AA. The Walking Dead. Apocalipsis zombi ya. Madrid, Errata naturae, 2012, p. 169.

${ }^{14}$ Ferrero, A. y RoAs, S. Op. cit.

15 Hardt, M. y Negri, A. Multitud. Guerra y democracia en la era del Imperio. Barcelona, Debate, 2004, p. 231.
}

CuCo, Cuadernos de cómic número 1. Septiembre de 2013

CuCoEstudio 
su intención. ${ }^{16}$ En este sentido, Kirkman parece más un pragmático autodidacta (¿otra vez Dumas?) que sabe hacer una lectura del contexto cultural de su tiempo (los EE. UU. posteriores al $11 \mathrm{~S}$ y en plena fiebre belicista con Irak y Afganistán) y que recoge todo el legado ideológico presente en el discurso político de su época. Me atrevería a afirmar que de forma no necesariamente consciente va a construir un discurso reaccionario, muy en la línea del pensamiento postmoderno, que tiene como gran éxito desplazar los conflictos de la clase o lo colectivo al individuo y a las cuestiones relativas a la identidad (género, religión, etnia...), ${ }^{17}$ desde luego alejado de la visión progresista de Romero.

De todas formas el pragmatismo de Kirkman convierte LMV en un producto flexible, que admite múltiples lecturas y que puede satisfacer tanto al lector progresista (yo me considero tal) como al más conservador. Un ejemplo de ello radica en las diferencias del elenco con la serie de AMC. En el cómic, entiendo que dirigido a un público bregado en mil batallas, fan, ya madurito y con cierta formación (incluso diría masculino y progresista) predomina un carácter de melting point, reflejo de la diversidad del ecosistema social $\mathrm{USA}^{18}$ aunque con una significativa ausencia, los red necks o "basura blanca", que paradójicamente están claramente omitidos en un dramatis personae que procede de la América profunda del sur (Rick, el agente de la ley convertido en figura principal en un reparto que es coral, es sin ir más lejos de Kentucky, como el propio Kirkman). En la serie de TV, por el contrario, dirigida a un público más juvenil y plural, hay dos personajes clave que se corresponden con el modelo white trash: los hermanos Merle y Daryl. A públicos diferentes, narraciones diferentes, y no creo que sea una simple cuestión de formatos.

\footnotetext{
${ }^{16}$ Ferrero, A. y Roas, S. Op. cit.

${ }^{17}$ NAÏR, S. "La modernidad en contra del choque de civilizaciones", en VV. AA. Frente a la razón del más fuerte. Barcelona, Galaxia Gutenberg, 2005, p. 51.

18 "Los personajes hacen de este cómic algo especial. Son tantos que forman un microcosmos literario rico y variado. Los hay de todas las clases, de todas las razas, de todas las etnias, de todas las profesiones, de todos los sexos y de todas las edades" en MATos, D. y Vicente, A. The Walking Dead. Caminando entre los muertos. Palma de Mallorca, Pretextos Dolmen, 2011, p. 56.
} 
Ya hemos esbozado la que va a ser nuestra idea base: Kirkman ha construido un producto eminentemente norteamericano, en palabras de Santiago García con dosis de "moralina y sentimentalidad sobre un mensaje político conservador". ${ }^{19}$ Un producto no exclusivamente postmoderno (por la temática de la identidad-individualidad) sino anclado en una potente tradición ideológica que está en los orígenes de los propios EE. UU. En este sentido, huye del zombi como metáfora política del biopoder totalitario o del propio capitalismo consumista y depredador para profundizar en los comportamientos morales del individuo superviviente en un contexto de crisis radical del sistema de valores. Ahí radica también curiosamente la fuerza simbólica de su relato.

\section{Negra Utopía}

El mundo que conocíamos ya no existe. El mundo del comercio y las necesidades superfluas ha sido reemplazado por un mundo de supervivencia y responsabilidad. (...) En cuestión de meses la sociedad se ha desmoronado, sin gobierno, sin supermercados, sin correo, sin televisión por cable. En un mundo gobernado por muertos, por fin nos vemos obligados a empezar a vivir.

Este significativo texto cierra cada uno de los volúmenes de la edición española de LMV y es un reflejo del estremecedor paisaje que va a construir Kirkman y en el que los zombis, caminantes o no muertos, como ya dijimos, son solo un elemento más o una excusa para edificar lo que Ernst Bloch calificó como "negra utopía” en la que "el paisaje del terror es también, como en El Bosco, voluptuoso y casi infinito en su ironía" ${ }^{20} \mathrm{Al}$ igual que en las pinturas del autor flamenco "en el lugar que es el infierno pasan muchas cosas, hay multitud de personajes y acontecimientos, todo es abigarrado, desordenado, porque el desorden es rasgo específico de la maldad y el pecado". ${ }^{21}$

\footnotetext{
${ }^{19}$ GARCÍA, S. Op.Cit., p. 135.

${ }^{20}$ DAVIS, M. Op. cit., p. 24.

${ }^{21}$ BozAL, V. "Riendo camino de la muerte", en VV. AA. El Bosco y la tradición pictórica de lo fantástico. Barcelona, Galaxia Gutenberg, 2006, p. 62.
} 
Kirkman "puede mirar al horror de Kurtz directamente a la cara y hacer una postal con eso". ${ }^{22}$ De hecho, su inspiración inmediata parece partir de infiernos más próximos en el tiempo y el espacio (y más reales) como puede ser la Europa de 1945, y sirvan como ejemplo las similitudes con este texto:

\begin{abstract}
Imaginemos un mundo sin instituciones. Es un mundo en el que las fronteras entre países parecen haberse disuelto, dejando un único paisaje infinito por donde la gente viaja buscando comunidades que ya no existen. Ya no hay gobiernos, ni a nivel nacional ni tan siquiera local. No hay escuelas ni universidades, ni bibliotecas ni archivos, ni acceso a ningún tipo de información. No hay cines ni teatros, ni desde luego televisión. ${ }^{23}$
\end{abstract}

Como en la Europa postbélica, el mundo de Kirkman ha asistido al derrumbamiento del sistema productivo, la pérdida o rarificación de los útiles básicos, la conversión del alimento en un bien escaso y sobre todo la destrucción del orden social, dando paso a un paisaje donde "los bienes solo pertenecen a aquellos lo bastante robustos para aferrarse a ellos y a los que están dispuestos a defenderlos con su vida" y en el que "hombres armados deambulan por las calles, cogiendo lo que quieren y amenazando a cualquiera que se interponga en su camino". ${ }^{24}$ Siguiendo esta vía, hay críticos que destacan la fascinación del autor de LMV por ese mundo postbélico y su naturaleza apocalíptica y marcada por la violencia y la desesperanza. ${ }^{25}$

Hay que entender que el concepto de paisaje representa desde la Ilustración un elemento clave en la conformación de las identidades individuales y colectivas, como escenario de la inocencia perdida y como tal complementario de la idea de niñez. ${ }^{26}$ En concreto, en el caso de los EE. UU. fue capital la construcción de una idealización del

\footnotetext{
22 DAVIS, M. Op. cit., p. 54. La cita original se refiere a la obra del fotógrafo Misrach, una "arqueología visual" del horror de los territorios en los que se realizaron ensayos nucleares en el oeste americano.

${ }^{23}$ Lowe, K. Continente salvaje. Europa después de la Segunda Guerra Mundial. Barcelona, Galaxia Gutenberg, 2012, p. 13.

${ }^{24}$ Ibid.

${ }^{25}$ MAtos, D. y ViCENTE, A. Op. cit., p. 59.

${ }^{26}$ LóPEZ SÁNDEZ, M. Paisaxe e nación. A creación discursiva do territorio. Vigo, Galaxia, 2008, p. 65.
} 
territorio como puro y virgen, "devoto y edificante" e incluso metáfora de la experiencia religiosa. ${ }^{27}$ En este sentido la contundencia del contrapaisaje kirkmaniano resulta brutal, aunque (como ya hemos venido afirmando a lo largo de este texto) no original.

De hecho, la tradición paisajista norteamericana encierra desde sus orígenes la contradicción entre el equilibrio natural y el desarrollo humano. Mike Davis señala por ejemplo el contraste entre la ciudad precapitalista, "una improvisación imperfecta y carnavalesca que cede a la transformación continua de un entorno mediterráneo dinámico", y la que denomina "gran ciudad americanizada" donde "la persecución de la utopía burguesa de un entorno totalmente calculable y seguro ha ocasionado paradójicamente una radical inseguridad". ${ }^{28}$ La imagen de Rick a caballo por las calles de una Atlanta abandonada al caos sería una poderosa metáfora del monstruo en el que se ha convertido la gran ciudad capitalista.

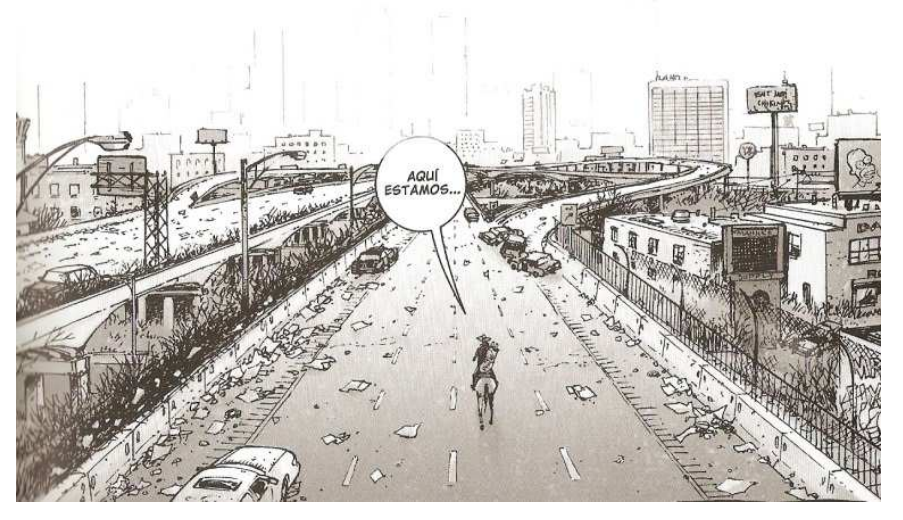

FIG. 1. Los muertos vivientes. N. ${ }^{\circ} 2$ (2004).

27 Hughes, R. Visiones de América. La historia épica del arte norteamericano. Barcelona, Galaxia Gutenberg, 2001, p. 151.

${ }^{28}$ DAVIS, M. Op. Cit., p. 23.

CuCo, Cuadernos de cómic número 1. Septiembre de 2013 
El caos supone por otro lado la oportunidad para la renaturalización de una sociedad enferma y el regreso a lo primitivo, a lo original, resumido en el concepto de verse obligado a empezar a vivir. ${ }^{29}$ Kirkman entronca así con la tradición ecologista norteamericana, comenzando por el propio Henry David Thoreau y su búsqueda de una forma de vida más auténtica y fuera de la opresiva economía de mercado:

Sería provechoso vivir una vida primitiva y de frontera, incluso en medio de una civilización volcada hacia lo exterior, aunque solo sea para aprender cuáles son las necesidades más importantes en la vida y qué métodos se han adoptado para satisfacerlas. ${ }^{30}$

El mismo Thoreau justificaba su retiro voluntario del mundanal ruido bajo el argumento de la necesidad de una vida más esencial, evitando curiosamente ser un muerto viviente:

Fui a los bosques porque quería vivir deliberadamente, enfrentándome solo a los hechos esenciales de la vida, y ver si podía aprender lo que la vida tenía que enseñar, no fuera que cuando estuviera por morir descubriera que no había vivido. No quería vivir nada que no fuera la vida, pues vivir es algo muy valioso, ni tampoco practicar la resignación, a no ser que fuera absolutamente necesario. $^{31}$

29 Brett Greeley, S. "Monstruos de la modernidad", en VV. AA. The Walking Dead. Apocalipsis zombi ya. Madrid, Errata naturae, 2012, p. 50. Una recopilación interesantísima sobre la literatura catastrofista y su cuestionamiento ecológico de la modernidad ya desde el siglo XIX se puede encontrar en DAVIS, M. Op. cit., pp. 215-230.

${ }^{30}$ ThOREAU, H.D. Walden. Madrid, Errata Naturae, 2013 [original de 1854], p. 18.

${ }^{31}$ Ibíd., p. 96.

CuCo, Cuadernos de cómic número 1. Septiembre de 2013

CuCoEstudio 


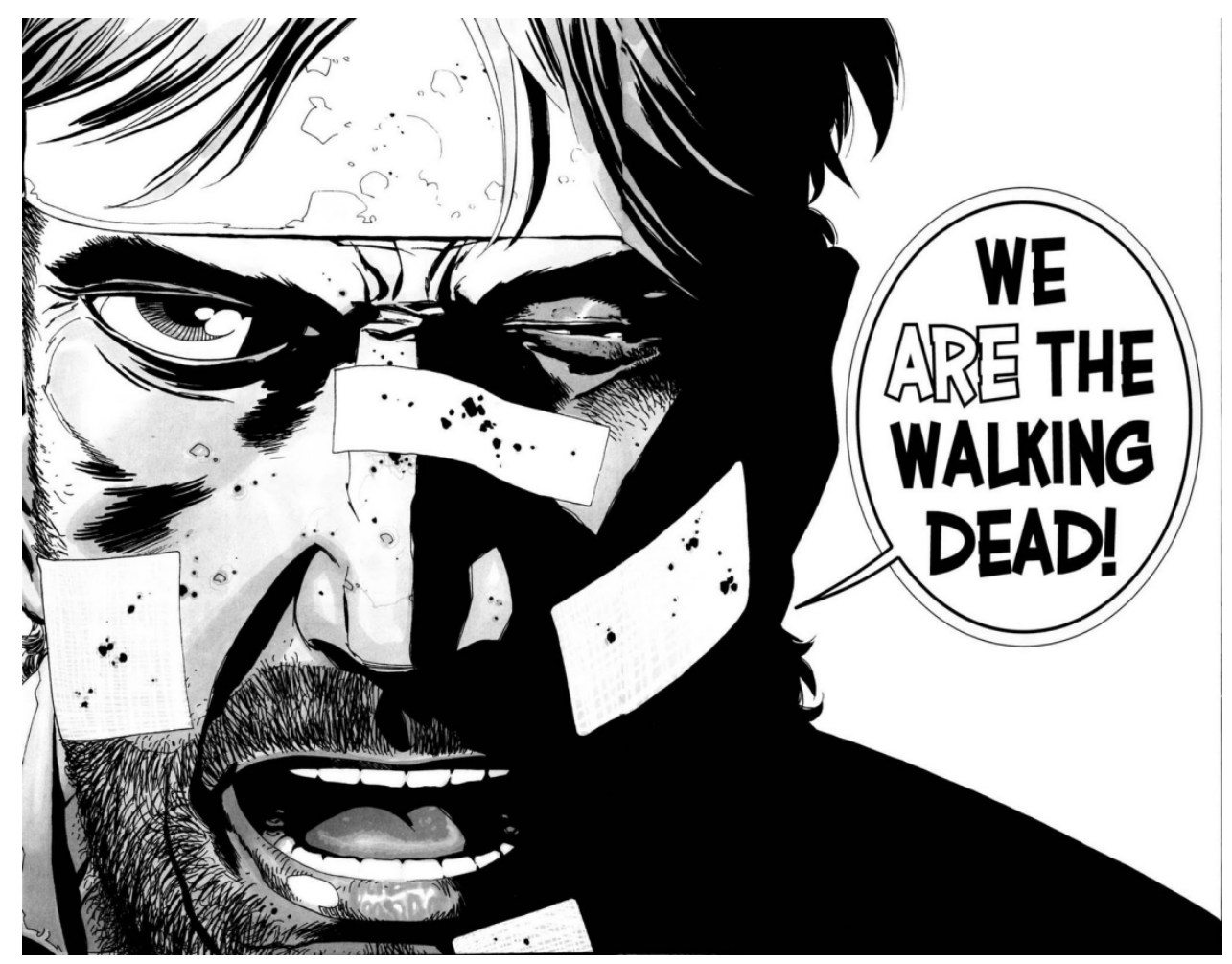

FIG. 2. The Walking Dead. N. ${ }^{\circ} 24$ (2006).

El apocalipsis zombi devolvería a los supervivientes a un estado de primitivismo $^{32}$ que rompe con la sofisticación consumista de la sociedad capitalista para basarse en "relaciones de poder, luchas por el liderazgo, por la dominación de bienes, mujeres o espacios que garanticen la supervivencia" ${ }^{33}$, retomando además el sentido de comunidad frente a la deshumanización de las megalópolis postmodernas. ${ }^{34}$ Una sociedad más auténtica en su salvajismo, que permite la reconstrucción desde valores nuevos que transcienden la molicie de la sociedad de consumo para superar la rutina vital. $^{35} \mathrm{Si}$ apuramos, podemos entroncarlo con los clásicos del liberalismo como

32 "La simplicidad y desnudez de la vida del hombre primitivo implica que este era, al menos, un habitante de la naturaleza. Una vez había repuesto sus fuerzas y calmado su hambre, volvía a contemplar el camino" (nótese que el aserto vale también para definir al zombi), vid. THOREAU, H.D. Op.Cit., p. 42.

${ }^{33}$ FERnÁNDEZ GONZALO, J. (2011), p. 69.

${ }^{34}$ Brett Greeley, S. Op. cit., p. 50.

${ }^{35}$ FERNÁNDEZ GONZALO, J. (2012), p. 70.

CuCo, Cuadernos de cómic número 1. Septiembre de 2013 
Tocqueville, que veían "la guerra y los grandes acontecimientos" como un "antídoto útil a nuestra mediocre sopa democrática y burguesa" "36 o el ecofascismo alemán, que observaba la destrucción bélica como una oportunidad para la "regeneración mística de la unidad aria con la naturaleza". ${ }^{37}$

La catástrofe guarda también relación con un concepto muy en boga, especialmente tras los acontecimientos del 11 de septiembre de 2001: la "sociedad riesgo". ${ }^{38}$ En este sentido la literatura apocalíptica y las negras utopías o contrapaisajes tendrían que ver con una "cultura del miedo" que limita las posibilidades reales de desarrollo personal del individuo quien "se ve forzado constantemente a tomar decisiones sin conocer sus posibles consecuencias", 39 acosado por amenazas de origen diverso (catástrofes ecológicas, pandemias, manipulación genética...). ${ }^{40}$ En palabras de Ramonet:

... los nuevos temores son menos de orden político o militar (conflictos, persecuciones, guerras) que de carácter económico y social (desastres bursátiles, hiperinflación, quiebras empresariales, despidos masivos, precariedad, recrudecimiento de la pobreza...), así como industrial (accidentes tan graves como los de Minamata, Seveso, Bhopal o Tolouse) y ecológico (trastornos de la naturaleza, deterioro del medio ambiente, calidad sanitaria de la alimentación, contaminación de todo tipo). Afectan tanto a lo colectivo como a lo íntimo (salud, alimentación...) y a la identidad (procreación artificial, ingeniería genética....). ${ }^{41}$

El miedo es un elemento esencial para el ejercicio del biopoder, "una forma de poder que regula la vida social desde el interior, siguiéndola, interpretándola,

\footnotetext{
${ }^{36}$ Losurdo, D. Contrahistoria del liberalismo. Barcelona, El Viejo Topo, 2005, p. 285.

${ }^{37}$ DAVIS, M. Op. cit., p. 234.

${ }^{38}$ La sociedad norteamericana estaría aquejada de "hipocondría aguda" motivada por una exacerbada cultura del miedo, vid. DAVIS, M. Op. cit., p. 18.

${ }^{39}$ ZIZEK, S. En defensa de la intolerancia. Barcelona, Público, 2010, p. 88.

${ }^{40}$ Ibíd., p. 83.

${ }^{41}$ RAMONET, I. "El ecosistema en peligro. Nuevos miedos, nuevas amenazas", en VV. AA. Frente a la razón del más fuerte. Barcelona, Galaxia Gutenberg, 2005, pp. 82-83.
} 
absorbiéndola y rearticulándola". ${ }^{42}$ En este sentido, los supervivientes de LMV se levantan de su propia alienación para construir un nuevo orden social donde son dueños de sí mismos y donde tendrán que combatir contra los caminantes y otros supervivientes si quieren mantener su libertad, lograda entre los restos de la civilización arrasada.

Debemos tomar aquí el concepto de civilización en su sentido fundamental: proceso de autoformación, de autoconstitución, mediante el cual el sujeto, ya sea colectivo (...) o individual (...) interioriza libremente valores y los asume para convertirlos en elementos de su identidad. ${ }^{43}$

La negra utopía kirkmaniana se inscribe además en el discurso derivado de la consolidación del sistema capitalista como propuesta única y que conduce a una visión de la catástrofe inevitable bien por agotamiento ecológico del planeta ${ }^{44}$ o bien por causas más aleatorias y ciertamente vinculadas a la tradición milenarista, como mantiene el pseudofriki movimiento Prepper, preparado para la contingencia de un hipotético derrumbe civilizatorio y que bien nos puede recordar a los sobradamente preparados supervivientes de LMV. ${ }^{45}$ A efectos medioambientales y sociales el capitalismo "funciona como la pandemia zombi, es el pensamiento de la horda: cubrir todo, arrasar todo" 46 con lo que los no muertos serían la representación de "la brutalidad de la estructura económica que consiente en un capitalismo dionisiaco, de bienes de consumo inútiles, tecnología de ocio regulada y espacios hipercodificados". ${ }^{4}$

\footnotetext{
${ }^{42}$ HARDT, M. y NEGRI, A. Imperio. Barcelona, Paidós, 2002, p. 38.

${ }^{43}$ NAÏR, S. Op. cit., p. 73.

${ }^{44}$ Vid. al respecto la "negra utopía” esbozada por el recientemente fallecido Ramón Fernández Durán, quien curiosamente también imaginaba la catástrofe como oportunidad de cambio, en FERNÁNDEZ DURÁn, R. La quiebra del Capitalismo Global: 2000-2030. Preparándonos para el comienzo del colapso de la Civilizacion Industrial. Madrid, Virus, 2011, p. 95.
}

45 AyUSO, M. “Así se organizan los preppers para sobrevivir al apocalipsis" en http://www.elconfidencial.com/alma-corazon-vida/2012/12/19/asi-se-organizan-los-preppers-parasobrevivir-al-apocalipsis-111424/

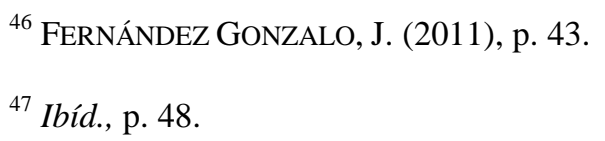

CuCo, Cuadernos de cómic número 1. Septiembre de 2013 
El capitalismo es una dinámica con un hambre terrible e insaciable: hay tanta ansiedad por engullir que se alcanza pronto el paroxismo (...). El discurso imperial es expansivo y caníbal en su naturaleza: hombres y mujeres devorados como mercancías consumibles. ${ }^{48}$

Los muertos vivientes constituyen de esta forma una poderosa metáfora pero está por ver si Kirkman la utiliza en este sentido, aunque sí que parece clara la reivindicación del individuo y la comunidad frente a la alienación (caminantes) y la irracionalidad (supervivientes hostiles), argumentos que retomaremos más adelante. Los paisajes apocalípticos de Kirkman no serían por tanto exclusivos de un derrumbe civilizatorio sino que habría la posibilidad de una interpretación en clave de crítica sistémica (repito, no necesariamente buscada por el autor mas potencialmente implícita para el lector). La Atlanta arrasada por la pandemia tiene su paralelismo real no solo en la ciudad bombardeada y postbélica sino también en los barrios barridos por el neoliberalismo especulativo que conforman en palabras del fotodocumentalista Camilo Vergara la "geomorfología del Gueto". 49

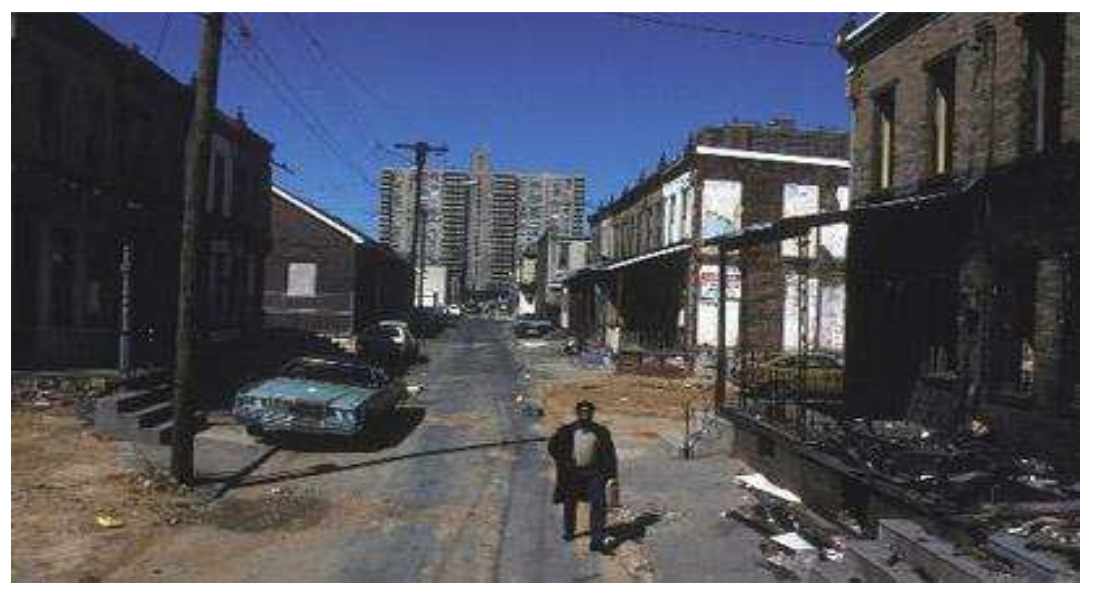

FIG. 3. Fotografía de Camilo José Vergara.

${ }^{48}$ MARzo, J. L. "Los métodos de Kurtz", en VV. AA. Planeta Kurz. Barcelona, Mondadori, 2002, pp. 108-109.

${ }^{49}$ DAVIS, M. Op. cit., pp. 238-244.

CuCo, Cuadernos de cómic número 1. Septiembre de 2013

CuCoEstudio 
El paisaje neoliberal como espacio de catástrofe nos conduce a un segundo escenario, el de la gestación del mismo, lo cual nos llevará inexorablemente a la caracterización del ecosistema político y socioeconómico norteamericano como el gran referente que de forma transversal define LMV.

\section{Made in USA}

Los Estados Unidos presentan tres episodios o hitos fundacionales que determinan de forma significativa su cultura política: la Guerra de Independencia (1775-1783), la Conquista del Oeste (en especial en el siglo XIX pero iniciada antes) y la Guerra de Secesión (1861-1865). Hablamos de un proceso histórico de Nation Building contradictorio, que combinó de forma ambivalente la emancipación (liberación de los colonos blancos) y desemancipación (esclavitud de los africanos, genocidio y desposesión de los nativos), "por un lado la rebelión comienza reivindicando la igualdad; por el otro apoyando y profundizando posteriormente la desigualdad". ${ }^{50}$ En palabras de Hardt y Negri las revoluciones y procesos nacionales anticolonialistas como el norteamericano "así como parecen progresistas en su función protectora contra la dominación externa (...) pueden pasar fácilmente a desempeñar el papel inverso en relación con el interior que protegen". 51 Podemos afirmar que esa contradicción es una constante metaliteraria a lo largo de LMV, que convierte dicha obra en un ejemplo paradigmático de la cultura política norteamericana.

Los padres fundadores concibieron la fundación de la República "como un momento ambivalente y contradictorio dentro de la dialéctica de la virtud y de la corrupción". ${ }^{52}$ Dicha ambivalencia está presente en LMV en forma de la contraposición

\footnotetext{
${ }^{50}$ LOSURDO, D. Op. cit., p. 298.

${ }^{51}$ HARDT, M. y NEGRI, A. (2002), p. 107.

52 Pocock, J. G. A. El momento maquiavélico. El pensamiento político florentino y la tradición republicana atlántica, Madrid, Tecnos, 2002 [original de 1975], p. 650.
} 
entre diferentes modelos políticos surgidos entre los supervivientes. En términos maquiavélicos, Rick y su grupo representarían la virtud, entendiendo como tal la defensa de la comunidad y el bien común mientras que por ejemplo el Gobernador, los cazadores o Negan serían la representación de la corrupción, entendida esta como la satisfacción de los intereses privados por encima del bienestar comunitario. ${ }^{53}$

(...) el poder ya no se concibe (...) como un medio para realizar los anhelos de la comunidad, sino como un fin en sí mismo: la única forma de "poder ser" frente a los otros; el poder absoluto y omnímodo como expresión suprema de la autoafirmación. $^{54}$

De todas formas, en la defensa del bien común el grupo de Rick puede llegar a traicionar sus valores como hicieron los propios padres fundadores, cuestión que trataremos más adelante al hablar del trasfondo ético de LMV. Aun así, no cabe duda de que Rick y los suyos aplicarán el principio rousseauniano de que el contrato social es el resultado de una agregación de fuerzas que produce un "cuerpo moral y colectivo". 55

\footnotetext{
${ }^{53}$ Ibíd., p. 583.

54 Ndongo-Bidyogo, D. "Los herederos del señor Kurtz", en VV. AA. Planeta Kurz. Barcelona, Mondadori, 2002, p. 128.

${ }^{55}$ Rousseau, J. J. Del Contrato social. Discursos. Madrid, Alianza, 2002 [original de 1762], p. 39.
} 


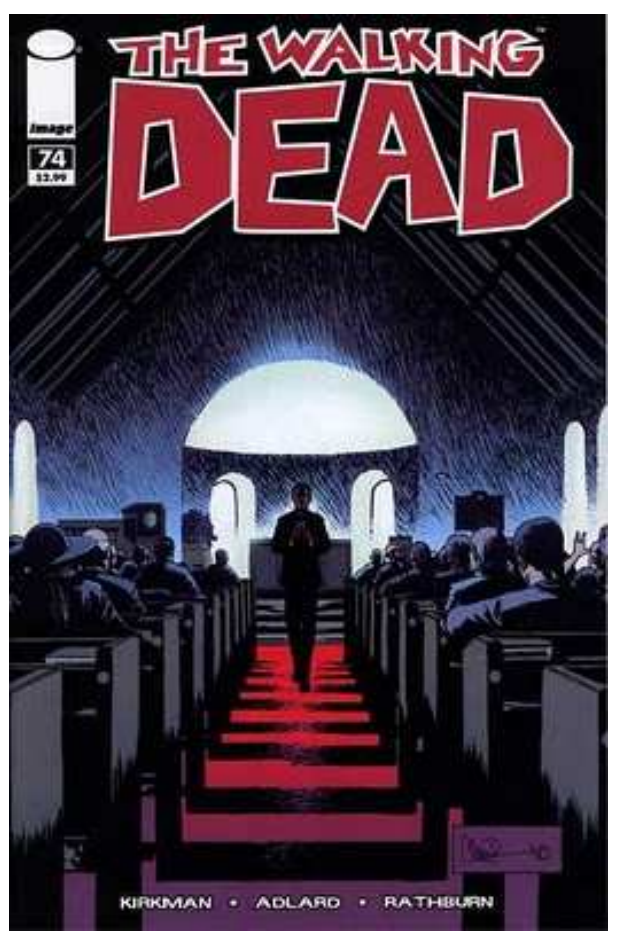

FIG. 4. The Walking Dead. N. 74 .

Las referencias a la conquista del Oeste son más explícitas, si cabe, comenzando por el propio carácter de western que con frecuencia se le atribuye a LMV. En primer lugar hay un reflejo consciente de "la violenta vida de frontera", ${ }^{56}$ comenzando por el derecho de posesión en función de la capacidad para ocupar y defender un territorio. ${ }^{57}$ Rick y los suyos estarían reconstruyendo en la catástrofe el "imperio de la libre propiedad" reproduciendo el sueño milenarista de la ciudadanía armada que coloniza un territorio virgen convirtiéndolo en una "reserva infinita de virtud". ${ }^{58}$ Para los primeros colonos (los puritanos del XVIII) "era la cultura - cercar, cultivar, construir- lo que

\footnotetext{
${ }^{56}$ BAGEANT, J. Crónicas de la América profunda. Barcelona, Los libros del lince, 2008, p. 199. Por cierto que la sustitución del sugerente título original (Deer Hunting with Jesus Dispatches from America's Class War) por el anodino Crónicas... es un reflejo de la desastrosa política editorial en lo referente a las traducciones, dicho con todo el respeto.

${ }^{57}$ Ibíd., p. 205.

${ }^{58}$ Pocock, J. G. A. Op. cit., p. 638.
}

CuCo, Cuadernos de cómic número 1. Septiembre de 2013

CuCoEstudio 
otorgaba derechos de propiedad", 59 para Rick la posibilidad de recrear el mundo nuevo pasa por esa culturización del territorio, tanto en el episodio de la prisión como en el arco argumental titulado significativamente "Un mundo más grande" (números 91-96 USA), contraponiéndose a los grupos que viven del saqueo o la matanza de otros. En este sentido Rick enlaza con la "Doctrina del Destino Manifiesto", que recalca el papel apocalíptico y utópico de una América sagrada, sucesora de los viejos imperios (Traslatio Imperii) como pueblo elegido. ${ }^{60}$

... las tierras salvajes por colonizar son como esa materia a la que urge dar forma: la naturaleza del americano como granjero libre (yeoman), como guerrero y como ciudadano, no asume una condición plena hasta que no ha adquirido forma. $^{61}$

Por otro lado, Rick también es consciente de la importancia de establecer relaciones entre las dispersas comunidades de supervivientes, como motor de un posterior desarrollo social, estableciendo el comercio como "fuente de todos los valores sociales", 62 aunque como percibían los padres fundadores existe el riesgo de que el comercio corrompa la república, y de ahí sus constantes reticencias y desconfianzas en los contactos con otros grupos (unido no cabe duda a algunas experiencias más que traumáticas).

Un segundo aspecto relacionado con la conquista del Oeste es el recurso al exterminio, previa deshumanización del Otro, a la hora de consolidar el control y el proceso civilizador del territorio:

La deportación y diezma de los indios explican el hecho de que el territorio norteamericano era una "cuna vacía", en espera del colonizador blanco, empeñado desde su llegada "en la lucha contra los obstáculos que la naturaleza les opone", en la lucha "contra el desierto y la barbarie": y una vez más, vuelve a

\footnotetext{
${ }^{59}$ Hughes, R. Op. cit., p. 33.

${ }^{60}$ Pocock, J. G. A. Op. cit., pp. 615-617 y 647.

${ }^{61}$ Ibíd., p. 643.

${ }^{62}$ Ibíd., p. 592.
}

CuCo, Cuadernos de cómic número 1. Septiembre de 2013

CuCoEstudio 
aparecer el proceso de deshumanización de los nativos, reducidos, más que a barbarie, a naturaleza inanimada. ${ }^{63}$

Esta cita de Losurdo parece especialmente indicada para comentar el arco argumental "Teme a los cazadores" (números 61-66 USA). ${ }^{64}$ En él, tras neutralizar la amenaza de un pequeño grupo de merodeadores caníbales, Rick y parte de su facción exterminan sin piedad $y$ con torturas a unos suplicantes enemigos que son deshumanizados. El exterminio va a ser justificado en aras de un bien mayor y tras despojar al Otro de su condición humana dada su corrupción absoluta.

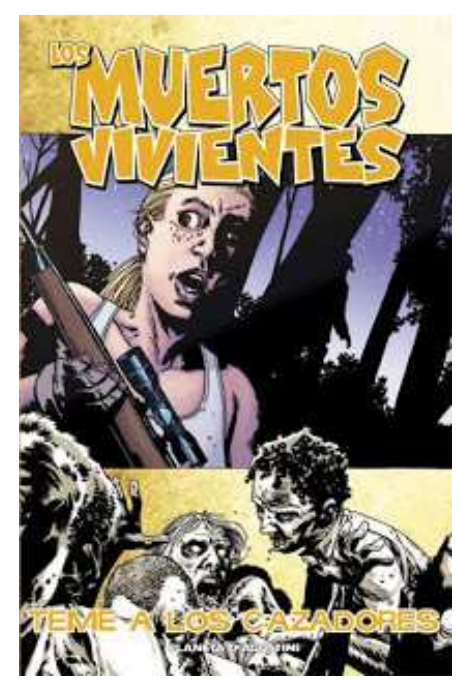

FIG. 5. Los muertos vivientes. Teme a los cazadores.

La justificación virtuosa de la violencia más cruel entronca con el tercer episodio fundacional de los EE. UU.: la Guerra de Secesión, la cual fue concebida como la resolución definitiva de las contradicciones de la construcción nacional y momento fundacional de unos EE. UU. industrialistas e imperiales.

La actual lucha entre el Sur y el Norte es, pues, en lo esencial un conflicto entre dos sistemas sociales, entre el sistema de la esclavitud y el del trabajo libre. La lucha ha estallado porque los dos sistemas no pueden coexistir en paz por más

\footnotetext{
${ }^{63}$ LosURDO, D. Op. cit., p. 233. Las citas literales son de Tocqueville.

${ }^{64}$ Matos, D. y ViCENTE, A. Op. cit., pp. 177-181.
} 
tiempo sobre el continente norteamericano. Esa lucha solo puede terminar con la victoria de uno o del otro. ${ }^{65}$

El conflicto con Woodbury y el Gobernador refleja ese espíritu de guerra total, de enfrentamiento radical entre dos concepciones políticas y que conduce necesariamente a la aniquilación ${ }^{66}$ del contrario, una "guerra eterna" que en palabras del mismísimo Thomas Jefferson "puede terminar o está destinada a concluir con el exterminio (extermination) de una de las partes". ${ }^{67} \mathrm{El}$ progresivo recurso de Rick y los suyos a una violencia cada vez más salvaje ha sido interpretado en clave ética como su particular corazón de las tinieblas. Mi opinión por el contrario es que además de esa lectura de carácter moral (que abordaremos en el último apartado) es posible una lectura complementaria y en clave política de estos comportamientos, perfectamente enmarcables en un contexto histórico caracterizado por el uso de la "violencia legítima" en defensa del "pueblo elegido" constituido en "comunidad de hombres libres",68 y que tiene en los USA como ejemplo extremo la defensa del libre uso individual de las armas.

Puedo vislumbrar la razón de que millones de urbanitas, cuyas familias vinieron de ciudades europeas y desembarcaron en la isla de Ellis, no alcancen a comprender los vínculos entre las armas, la supervivencia y el patriotismo de los primeros colonos celtas y germánicos que habitaron estas tierras. ${ }^{69}$

De esta forma, LMV bebe de un mesianismo crónico en la cultura política norteamericana que convierte en particular el periplo de Rick en una "misión” (la

\footnotetext{
${ }^{65}$ MARX, K. y Engels, F. La guerra civil en los Estados Unidos. México, Ediciones Roca, Colección R, n. ${ }^{\circ}$ 31, 1973, p. 99. El libro es una recopilación de escritos principalmente periodísticos que los padres del socialismo científico elaboraron durante el conflicto, agrupados en dos volúmenes.

${ }^{66}$ En última instancia el efecto buscado por la guerra es el aplastamiento de la otra parte en forma de limitación de sus posibilidades de desarrollo, vid. Soto, L. G. Paz, guerra e violencia. A Coruña, Espiral Maior, 2003, p. 94 y ss. Nótese que en el texto original en galego Soto utiliza la palabra esmagamento, que viene a significar la reducción de un sólido a pulpa o papilla.

${ }^{67}$ LOSURDO, D. Op. cit., p. 292. Obviamente el contexto en que Jefferson dice estas palabras es anterior a la Guerra Civil, correspondiéndose con la guerra contra los británicos de 1812.

${ }^{68}$ Ibíd., p. 284 y Pocock, J. G. A. Op. cit., p. 614.

${ }^{69}$ BAgEANT, J. Op. cit., pp. 127-128.
}

CuCo, Cuadernos de cómic número 1. Septiembre de 2013

CuCoEstudio 
protección de su familia y del grupo) que cuando fracasa le hace caer en la más absoluta patología. ${ }^{70}$ En la lucha por conseguir la misión, el grupo se desplaza buscando un lugar en el que establecerse, con un particular nomadismo (otra vez el western) que está enraizado en el espíritu fundacional de la Nación (“democracia de frontera”). ${ }^{71}$

Precisamente la Guerra Civil de la década de 1860 marca el principio del fin de dicha democracia de frontera, explicitado a partir de 1890 con la resolución de la conquista del Oeste a partir de la matanza de Wounded Knee que pone fin a la resistencia india ${ }^{72}$ y abre la puerta a un particular apocalipsis nativo, la Ghost Dance, que va a creer en el retorno de los pueblos indios "después de que la civilización blanca fuera destruida por una catástrofe autoprovocada". ${ }^{73}$ El final de la conquista del Oeste se va a plasmar en la construcción de un nuevo territorio, hiperurbanizado, en palabras de Mike Davis:

... un paisaje irrevocablemente social, transformado por el militarismo, la urbanización, la autopista interestatal, el vandalismo epidémico, el turismo masivo y el ciclo de auge y fracaso de las industrias extractivas.74

En otras palabras, el paisaje apocalíptico del capitalismo extremo, como ya dijimos. Es curioso que este periodo de cambio, ubicado entre las décadas finales del XIX y la primera del XX, sea conocido en la historia cultural como el "Renacimiento Americano" o la "Edad de Oro", 75 ya que coincide al mismo tiempo con "el más intenso y enconado conflicto de clases jamás vivido en América", unos EE. UU. unificados

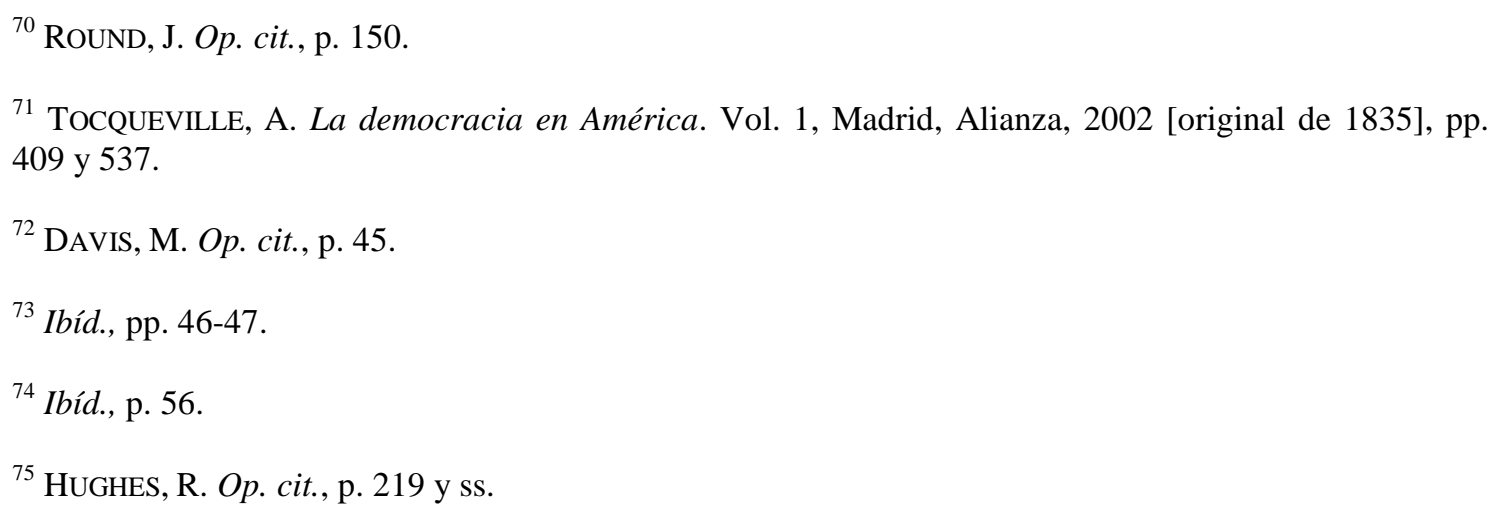

CuCo, Cuadernos de cómic número 1. Septiembre de 2013 
políticamente por la Guerra de Secesión pero no socialmente. ${ }^{76}$ El resultado del cambio fue un capitalismo basado en una fuerte división social y una intensa urbanización, lo que nos lleva a dos últimos aspectos a tratar relacionados con el trasfondo de LMV.

En primer lugar retomaremos un tema esbozado en el apartado anterior y que por sí mismo sería cuestión para un estudio monográfico, hablamos de la visión de la ciudad. En la temática zombi es frecuente la caracterización de la ciudad como una trampa, un entorno hostil, una ratonera en la que te ves atrapado por la pandemia e incapaz de sobrevivir ante el caos ocasionado por el derrumbe del orden básico. Un ejemplo de esta visión está en la última superproducción World War Z (Marc Forster, 2013) en la que quienes permanecen en los centros urbanos son literalmente aniquilados por la combinación del caos y la plaga. Ya mencionamos por otro lado que las grandes ciudades que aparecen en LMV (Atlanta, Washington) son zonas no seguras de las que hay que alejarse para sobrevivir. La cuestión es que la clase media norteamericana lleva protagonizando una huida del centro de las ciudades desde después de la II Guerra Mundial, intensificada a partir de las políticas neoliberales de Reagan, en un auténtico apartheid espacial marcado por la división entre blancos y no blancos. ${ }^{77}$ Un vistazo de las "zonas seguras" de LMV (Woodbury, Alejandría, La Cima) establece un elemento común en su naturaleza de edge cities, ciudades satélite autosuficientes y con una marcada autonomía política que forman la llamada "suburbiolandia", un conjunto de "utopías burguesas" con "una autonomía política inaudita frente a la crisis del centro urbano". ${ }^{78} \mathrm{Su}$ carácter fortificado es también una poderosa metáfora de la gated communities, ${ }^{79}$ urbanizaciones superexclusivas y fuertemente dotadas de medidas de seguridad (las "casitas del barrio alto" del malogrado Víctor Jara), características de

\footnotetext{
${ }^{76}$ Ibíd., p. 225.

${ }^{77}$ DAVIS, M. Op. cit., pp. 169-174.

${ }^{78}$ Ibíd., pp. 170 y 173-174.

${ }^{79}$ http://en.wikipedia.org/wiki/Gated_community
}

CuCo, Cuadernos de cómic número 1. Septiembre de 2013

CuCoEstudio 
sociedades fuertemente polarizadas (por tanto no exclusivas de EE. UU.) y que tienen en la Agrestic de la serie televisiva Weeds (Showtime, 2005-2012) la parodia suprema.

Toda esta degradación urbana (feliz casualidad que esa Atlanta hostil de LMV compita en la realidad con Detroit "por tener el honor de ser el "donut urbano" perfecto: negro en los centros desindustrializados, blanco en el anillo rico en empleo" ${ }^{80}$ ) repito que está vinculada con una fuerte polarización social y por tanto está en los orígenes del capitalismo norteamericano, donde son frecuentes la violencia y la delincuencia, además del conflicto interétnico, con ejemplos extremos como los disturbios de New York durante la Guerra Civil, ${ }^{81}$ los de la huelga de policías de Boston en $1919,{ }^{82}$ o los de California en la década de $1960^{83}$ o en $1992 .^{84}$ Todo lo cual por supuesto genera en las clases medias y acomodadas una percepción de la megalópolis como un espacio violento y peligroso (otra vez la idea de la sociedad de riesgo) un entorno hostil y por otro lado va a provocar también la demanda de políticas de orden basadas en la seguridad.

Y aquí vendría el segundo aspecto a tratar y con el que cerraremos este apartado, la construcción en los USA de un auténtico "Estado Penal" y de lo que en LMV encontramos una poderosa metáfora en los arcos argumentales ubicados en la prisión: desde "Seguridad tras los barrotes" (13-18 USA) a "Creados para sufrir" (43-48 USA), que además coinciden con el largo conflicto con Woodbury y el Gobernador. ${ }^{85}$ Ya mencionamos anteriormente que para los primeros colonos la idea de cultura pasaba por acotar y cultivar el territorio. En este sentido, resulta desconcertante que la primera vez

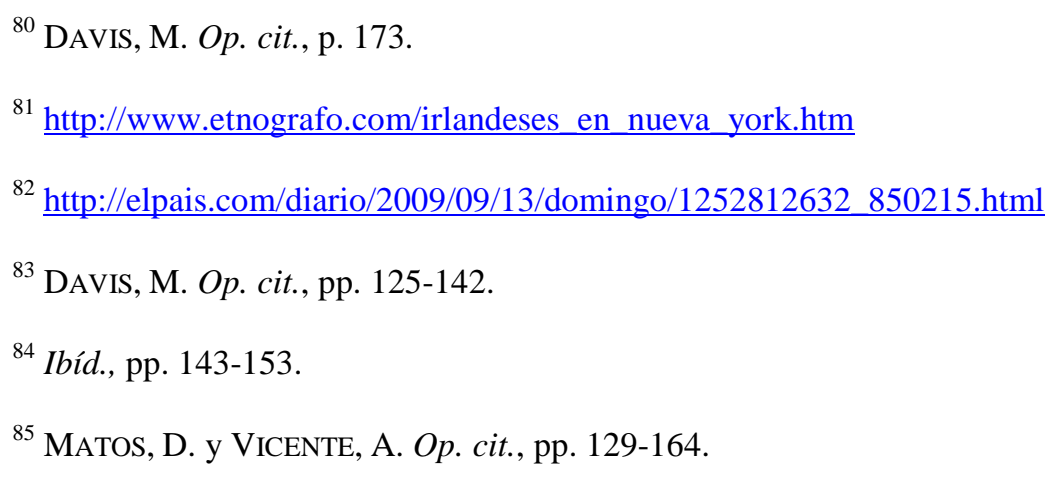

CuCo, Cuadernos de cómic número 1. Septiembre de 2013 
que aparece este concepto cultural en LMV sea precisamente en la prisión, donde están seguros "tras los barrotes" y se plantean comenzar de nuevo cultivando la tierra.

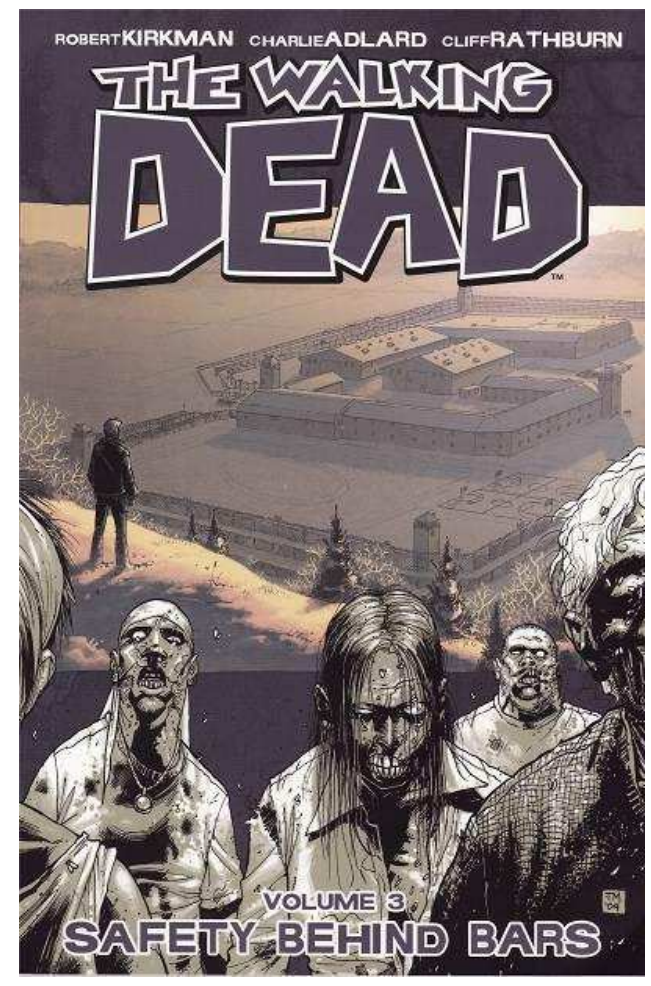

FIG. 6. The Walking Dead. Safety behind bars.

La prisión como institución es una respuesta al "carácter arriesgado e inseguro de las actuales relaciones socioeconómicas" que va a impulsar "nuestros esfuerzos obsesivos por vigilar a los individuos peligrosos, aislar a los grupos de riesgo e imponer controles sobre entornos abiertos y no regulados". ${ }^{86}$ Rick logra convertir la prisión en una "zona segura" donde precisamente el grupo puede ejercer el control sobre los nomuertos y el territorio, aunque con el riesgo de conducir la comunidad de hombres libres cara una deriva autoritaria con el recurso por ejemplo a la ejecución sumaria. ${ }^{87}$

${ }^{86}$ GARLAND, D. "Lucha contra el crimen y modernidad tardía en Estados Unidos y Gran Bretaña", en Archipiélago, n. ${ }^{\circ}$ 55, 2003, p. 102.

${ }^{87}$ Matos, D. y ViCENTE, A. Op. cit., pp. 132-133.

CuCo, Cuadernos de cómic número 1. Septiembre de 2013

CuCoEstudio 
... encontramos ahora la imposición de regímenes más intensivos de regulación, inspección y vigilancia, y de esta forma nuestra cultura cívica se hace cada vez menos tolerante y receptiva, cada vez menos dispuesta a confiar. Después de un largo proceso de expansión de la libertad individual y descenso de las limitaciones socioculturales, el control se reafirma en cualquier área de la vida social — con la excepción singular y espantosa de la economía, de cuyo entorno desregulado surge día a día la mayoría de los actuales riesgos. ${ }^{88}$

La prisión como refugio seguro opino que rompe ese aserto antes comentado de que los zombis de Kirkman están despolitizados. Por el contrario, la prisión (el Estado Penal) es un dique frente a la horda, esos delincuentes ansiosos que buscan invadir y devorar el espacio de los hombres de bien, donde "las ansiosas clases medias actuales buscan resolver su ambivalencia mediante un control celoso de los pobres y una exclusión no menos afanosa de lo marginal". ${ }^{89}$ La cárcel como garantía para nuestras libertades y freno de aquellos que desde el exterior del sistema las amenazan, no puede haber un mensaje más político.

El Estado Penal supone también la asunción del crimen como una patología individual, derivada de una postura personal y por lo tanto moral. ${ }^{90}$ La respuesta de Rick ante la violación de la norma es por tanto sumarísima, "si matas, mueres". El castigo del crimen como patología resultante de una elección racional (y por lo tanto malvada) nos llevará a la tercera y última reflexión y que en el fondo es el componente más explícito del constructo kirkmaniano: el trasfondo ético y la crisis moral.

\section{La muerte del ideal rousseauniano}

En The Walking Dead el miedo, el terror, por lo desconocido, por aquellos otros que, aunque muertos, caminan, buscan, merodean y atacan, existe; pero en la obra de Kirkman, la mayoría de las veces, esa desazón se ve sustituida por otra realidad

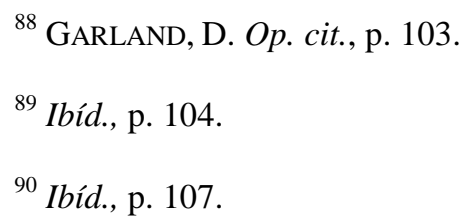


aterrorizante: los hombres sin esperanzas, sin leyes, sin normas morales, son peores que los muertos, capaces de realizar todo tipo de atrocidades. ${ }^{91}$

Todo el camino que venimos recorriendo nos conduce a un inevitable final, la caracterización de LMV como una obra significativamente moralista, que encierra una dimensión ética evidente y en clave incluso existencial, como sugiere Julia Round al insistir en que nos sitúa frente al absurdo y la necesidad de aceptar la carencia de "un propósito y sentido morales" en nuestra vida. ${ }^{92}$ Por tanto, toda la teoría de la bondad natural del ser humano que estableció una idea optimista y racionalista de progreso desde la Ilustración deja paso a una visión desoladora donde parece hacerse realidad aquel ideal hobbesiano del homo homini lupus. En esta línea, el regreso al primitivismo de los supervivientes no supone regresar a un estadio donde "la piedad es un sentimiento natural que, moderando en cada individuo la actividad del amor de sí mismo, concurre a la conservación mutua de toda la especie" ${ }^{\text {"93 }}$ sino que va a implicar la imposición de una "ambición devoradora" que en el afán de sobrevivir va a inspirar "a todos los hombres una negra inclinación a perjudicarse mutuamente". ${ }^{94}$ Paradójicamente, en términos rousseanianos los supervivientes han pasado a un estadio de civilización. Así fue como haciendo los más poderosos o los más miserables de su fuerza o de
sus necesidades una especie de derecho a los bienes ajenos, equivalente según
ellos al de propiedad, a la igualdad rota siguió el más horroroso desorden; así fue
como las usurpaciones de los ricos, los bandidajes de los pobres, las pasiones
desenfrenadas de todos, ahogando la piedad natural y la voz aún débil de la
justicia, volvieron a los hombres avaros, ambiciosos y malvados.

\footnotetext{
${ }^{91}$ Matos, D. y ViCENTE, A. Op. cit., p. 9.

${ }^{92}$ Round, J. Op. cit., pp. 151 y ss.

93 Rousseau, J. J. Op. cit., p. 267. La cita en concreto procede del Discurso sobre el origen y los fundamentos de la desigualdad entre los hombres escrito en 1753.

${ }^{94}$ Ibíd., p. 291.

${ }^{95}$ Ibíd., p. 292.
}

CuCo, Cuadernos de cómic número 1. Septiembre de 2013

CuCoEstudio 
Otra paradoja va a ser el papel de Rick, un funcionario público y como tal representante del viejo orden, como pionero en comprender la necesidad de asumir un orden nuevo, violento, cruel y dotado de una nueva moral potencialmente nihilista en la que "los valores supremos se desvalorizan" y "se acepta el absurdo como punto de partida". ${ }^{96}$ LMV serían una metáfora del caos ético al que parece conducir la Globalización inspiradora de ese "mato, luego existo" que tuvo como corolario el atentado suicida del $11 \mathrm{~S}^{97}$ En ese sentido, Kirkman podría estar construyendo intuitivamente un discurso legitimador de la ultraviolencia como defensa y camino de emancipación frente al absurdo y la fuerza del terror, donde "la arbitrariedad, en cuanto que forma de azar se vuelve insoportable, especialmente cuando se pretende combinar con la justificación de una ley determinista". ${ }^{98}$

Hay que aclarar que esta interpretación en clave nihilista tiene un explícito contenido político. En este sentido, los nuevos reaccionarios como Glucksmann justifican el combate del "mal absoluto", aquel que en su cultura de la muerte simplemente se resume en el odio total, como una patente de corso para imponer la fuerza de la razón liberal-capitalista basada en los valores "republicanos, occidentales, judeocristianos, según se quiera". ${ }^{99}$ En otras palabras, olvidando el ideal rousseaniano y observando en el Otro la caracterización del mal, podemos observar impávidos e incluso aplaudir como Michonne machaca al Gobernador o Rick tortura y asesina a los cazadores. El equivalente real serían Guantánamo o los bombardeos en Gaza.

Si Rousseau dijo que los hombres son naturalmente bondadosos es porque su bondad —indemostrable — obliga a explicar por qué se vuelven malos; si Voltaire insistió en que razonable es aquello que todos los hombres piensan por igual cuando están tranquilos es porque esa racionalidad común — también indemostrable - obliga a explicar por qué se acaloran o qué fuerzas los

\footnotetext{
${ }^{96}$ Glucksmann, A. Dostoievski en Manhattan. Madrid, Taurus, 2002, p. 70.

${ }^{97}$ Ibíd., p. 24.

${ }^{98}$ MARtínez LuCEnA, J. y BARrayCoA MartíneZ, J. "El zombi y el totalitarismo: de Hannah Arendt a la teoría de los imaginarios”, en Imagonautas, n. 2, 2012, p. 108.

${ }^{99}$ JOFRIN, L. “Los nuevos reaccionarios”, en Archipiélago, n. ${ }^{\circ}$ 72, 2006, p. 85.
} 


\section{intranquilizan. Si el hombre es naturalmente malo e irracional, entonces todo está explicado ya. ${ }^{100}$}

En otras palabras, Kirkman está construyendo un relato sobre el bien y el mal, aunque sus representantes del bien presenten zonas grises. En dicho relato no es preciso explicar la razón o el origen de la maldad, simplemente es presentada de forma aterradora y nos hace desear el justo castigo, la reparación. Un relato bien distinto de otros que como Conrad elaboraron un retrato del horror como consecuencia de la debilidad y de la corrupción de la condición humana y por lo tanto aportaron junto con la descripción del crimen la necesidad de la compasión.

Pero su alma estaba loca. Al encontrarse sola en la selva había mirado dentro de sí misma y, ¡santo cielo!, os lo aseguro, se había vuelto loca. Yo mismo tuve que pasar — supongo que a causa de mis pecados - por la dura prueba de mirar en su interior. (...) Vi el inconcebible misterio de un alma que no conocía el freno, ni fe, ni miedo, y que, no obstante, luchaba ciegamente consigo misma. ${ }^{101}$

Lo que sí tienen en común Kirkman y Conrad es un profundo pesimismo sobre la condición humana (en el caso concreto del gran escritor producto de su contacto directo con el horror colonial en el Congo). Como respondiendo a la frase de Sartre, "el infierno son los otros", los protagonistas de LMV afrontan una experiencia en la que "el peor enemigo del hombre son los otros hombres, pues al fin y al cabo los zombis tan solo hacen lo que tienen que hacer, que no es otra cosa que comerse a los supervivientes (...), a diferencia de nosotros, no odian". ${ }^{102}$ En palabras de Fernández Gonzalo "el verdadero peligro de la humanidad es una sociedad intolerante, que rinde culto a las armas y no se da cuenta de su propia irracionalidad". ${ }^{103}$

\footnotetext{
100 Alba RiCO, S. "La construcción del mal: instrucciones”, en Archipiélago, n. o 72, 2006, p. 95, (el subrayado es nuestro).

${ }^{101}$ CONRAD, J. El corazón de las tinieblas. Madrid, Alianza, 1991 [original de 1902], p. 113.

${ }^{102}$ FuENTES, A. "El camino del zombi", en VV. AA. The Walking Dead. Apocalipsis zombi ya. Madrid, Errata naturae, 2012, p. 187.

${ }^{103}$ Fernández Gonzalo, J. (2011), p. 39.
} 
LMV por tanto es un reflejo de la paradoja postmoderna, el fin de una idea de progreso y la crisis de unos valores que desde el Renacimiento condujeron a la cultura occidental al dominio del planeta, eso sí, utilizándolos para dentro pero obviándolos en la aniquilación del Otro (el enemigo interior o exterior).

Por un lado, el humanismo del Renacimiento inauguraba una noción revolucionaria de igualdad, de singularidad y de comunidad humanas, de cooperación y de multitud,, que armonizaba con las fuerzas y los deseos que se extendían horizontalmente por todo el globo (...). Sin embargo, por el otro, el mismo poder contrarrevolucionario que procuraba controlar las fuerzas constitutivas y subversivas dentro de Europa también comenzó a advertir la posibilidad y la necesidad de subordinar las otras poblaciones a la dominación europea $^{104}$

El zombi por otro lado sirve para situar la humanidad ante su propia contradicción y su doble moral, "el zombi no desea nada (salvo la expansión y la saciedad, pero eso ya son cosas del instinto), frente a los hombres que desean demasiado, que se traicionan, que se engañan, se asesinan o se violan", ${ }^{105}$ reflejando que el principal miedo del ser humano es "hacia sí mismo"106, ya sea en la forma de caminante ya como los supervivientes hambrientos de dominación, practicantes unos y otros de "una corrupción siempre al acecho, esperando la víctima más débil para saltar encima y devorarla; es entonces cuando los despojos sirven para alimentar al resto de la manada". 107

Los villanos de LMV serían una representación en términos maquiavélicos del "hombre no virtuoso" (y por lo tanto estaríamos ante una historia sobre del declive de la virtud y el ascenso de la corrupción), constituyéndose en "una criatura de sus pasiones y de sus fantasías", ${ }^{108}$ en los que "el deseo de adquirir es, verdaderamente, algo muy

\footnotetext{
${ }^{104}$ HARDT, M. y NEGRI, A. (2002). p. 83.

${ }^{105}$ Fernández Gonzalo, J. (2011), p. 78.

${ }^{106}$ Ibíd., p. 146.

${ }^{107}$ MARZO, J. L. Op. cit., p. 118.

${ }^{108}$ Pocock, J. G. A. Op. cit., p. 624.
}

CuCo, Cuadernos de cómic número 1. Septiembre de 2013

CuCoEstudio 
natural y ordinario". ${ }^{109}$ Pero el propio Rick cae en la tentación de justificar la inmoralidad de sus actos y por lo tanto legitimar sus crímenes, ${ }^{110}$ insertándose en la tradición norteamericana (y liberal) de la guerra justa, en palabras de Grocio "la que se hace a los animales feroces y, después, la que se hace a los hombres que se asemejan a los animales feroces". ${ }^{111}$ Para evitar el conflicto moral que supone la eliminación del Otro (ya sea zombi o superviviente) será preciso construir la alteridad, situar al enemigo en un espacio o realidad existencial distinta, excluirlo. ${ }^{112}$ Así puede vencer Rick en el debate con aquellos que cuestionan su política sumarísima, bien con los caminantes (Hershel) o bien con otros supervivientes. Utilizando términos de Martínez Lucena y Barraycoa Martínez, el terror ha servido como "disolvente de estructuras" y la comunidad ha de consensuar "nuevas normas y roles" con lo que "los supervivientes se han contagiado de la ley de la evolución de la que escapan". 113

Pero la producción de alteridad tiene una función catárquica, ya que paradójicamente la cultura de la muerte despierta al superviviente que deja de ser un reflejo de los muertos vivientes. ${ }^{114}$ En palabras de Thoreau "si un hombre está vivo, siempre hay peligro de que muera, aunque hay que admitir que el peligro es menor en la medida en que el hombre se va convirtiendo en un muerto en vida". ${ }^{115}$ Los supervivientes en su construcción de una nueva moral darwinista han empezado a vivir.

Rick piensa que los integrantes de su grupo han dejado de vivir vidas auténticas: no admiten que sus circunstancias han cambiado y aún piensan que la "sociedad"

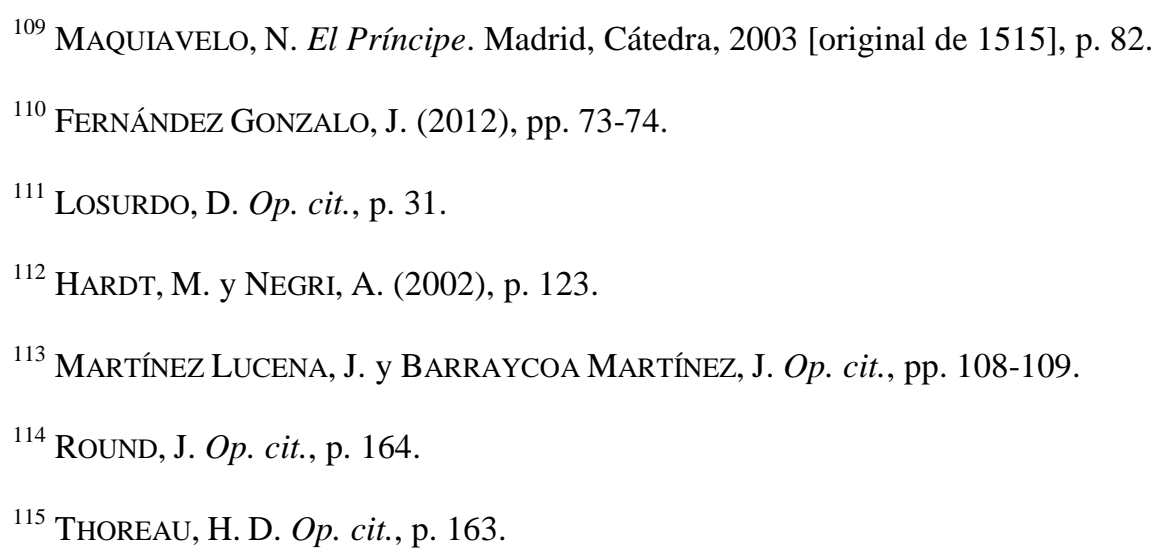


vendrá a rescatarlos del caos. Los integrantes del grupo de Rick necesitan dejar de ser zombis ellos mismos, necesitan ser auténticos, si quieren sobrevivir. ${ }^{116}$

Rick, Andrea, Michonne, Abraham, el propio Carl, mueren como participantes de una moral antigua para resucitar como miembros de un mundo nuevo, experiencia que desgraciadamente ha sido una constante en la Historia especialmente con el desarrollo de los sistemas totalitarios.

Para que unos hombres maten a otro gran grupo de gente, es preciso eliminar las restricciones éticas y emocionales que normalmente les impiden adoptar una medida tan radical. Algo profundo debe sucederles antes de que se conviertan en perpetradores voluntarios de una enorme matanza genocida. ${ }^{117}$

Todo lo cual los sitúa en una dimensión ética similar a la del Gobernador y hay que decir que Kirkman no lo oculta aunque manipula la narración de forma que llegamos a empatizar con ellos desde el horror. El nuevo mundo es un espejo del viejo y únicamente conduce al extremo conductas que pasan de estar penadas por la ley moral o jurídica a ser una realidad absolutamente asumida de la que nos podemos defender o a la que podemos recurrir según sea el caso: el abuso sobre mujeres y niños, el asesinato, el autoritarismo... Por lo tanto, en ese nuevo mundo está reflejada toda la crueldad del viejo, comenzando por la insistencia lockiana en "el derecho que tiene todo hombre de aniquilar a aquellos que han sido reducidos al rango de "animal de presa". ${ }^{118}$ Kirkman elabora un discurso sobre la inevitabilidad del conflicto, ya que la categoría de superviviente o "la pertenencia común (...) a la comunidad de los libres no garantiza la permanencia de las relaciones de amistad y de paz entre ellos", ${ }^{119}$ con lo cual en ese estado de guerra permanente asistimos a la liquidación definitiva del optimismo filosófico y de la idea de progreso.

\footnotetext{
${ }^{116}$ Round, J. Op. cit., pp. 164-165.

117 Goldhagen, D. J. Los verdugos voluntarios de Hitler. Los alemanes corrientes y el Holocausto. Madrid, Taurus, 1997, p. 510.

${ }^{118}$ LOSURDO, D. Op. cit., pp. 33-34.

${ }^{119}$ Ibíd., p. 287.
} 
En el centro de las esperanzas y de la sensibilidad ética modernas está la convicción de que la guerra, aunque inevitable, es una aberración. De que la paz, si bien inalcanzable, es la norma. Desde luego, no es así como se ha considerado la guerra a lo largo de la historia. La guerra ha sido la norma, y la paz, la excepción. $^{120}$

En términos rousseanianos, los supervivientes "acaban por asumir el derecho del más fuerte", hecho inevitable si no quieren sucumbir en una esfera de conflicto absoluto y permanente, ${ }^{121}$ qué metáfora más adecuada para explicar las relaciones internacionales. Aunque no hay que olvidar que toda persona en un momento determinado puede llegar a sentir "la fascinación de la abominación; ya sabéis, imaginaos el creciente arrepentimiento, el ansia de escapar, la impotente repugnancia, la renuncia, el odio". ${ }^{122}$ Lo que no me queda claro es si la siguiente cita del Corazón de las Tinieblas sería aplicable al caminante o al superviviente:

Se apoderaban de todo lo que podían por simple ansia de posesión, era un pillaje con violencia, un alevoso asesinato a gran escala y cometido a ciegas, como corresponde a hombres que se enfrentan a las tinieblas. ${ }^{123}$

\footnotetext{
${ }^{120}$ Sontag, S. Ante el dolor de los demás. Barcelona, Círculo de Lectores, 2003, p. 98.

${ }^{121}$ Rousseau, J. J. Op. cit., p. 29.

${ }^{122}$ CONRAD, J. Op. cit., p. 22.

${ }^{123}$ Ibíd.
} 

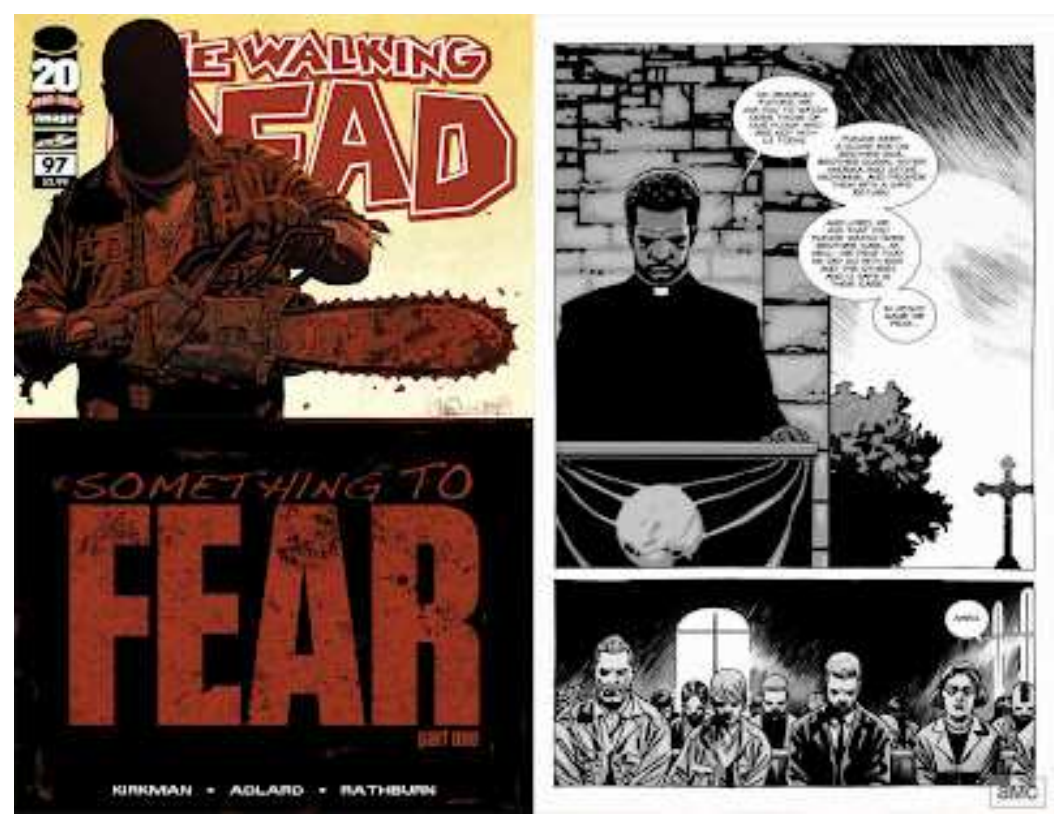

FIG. 7. The Walking Dead. N. ${ }^{\circ} 97$, portada y página interior.

\section{Coda final}

Quedaron cosas en el tintero. Por ejemplo, sería interesante el estudio tanto de las relaciones de género como de la identidad sexual (por ejemplo la homosexualidad aparece explicitada en el cómic y no así en la serie de TV) y el uso de la sexualidad como instrumento de dominación y control (el papel de la violación, por ejemplo, tanto de mujeres como de niños). La crisis de la pareja y del concepto tradicional de familia también es un tema destacado. Por otro lado, todo el arco argumental del Gobernador es un compendio acerca de los sistemas totalitarios con la tortura como forma de gobierno, la corrupción moral de los verdugos, el uso de la demagogia como fuente de movilización social. La visión de la infancia, con la durísima historia de la bajada a los infiernos de los niños, especialmente dura en el personaje de Carl, nos introduce en realidades como la de los niños soldados de los Estados fallidos...

LMV como producto cultural tiene esa capacidad inspiradora que desborda el marco de esta reflexión. Aun así, esperamos haber conseguido el que era nuestro

CuCo, Cuadernos de cómic número 1. Septiembre de 2013

CuCoEstudio 
objetivo inicial: realizar una lectura política de un cómic soberbio, que deja bien atrás ese estado de infantilización con el que algunos (por ignorancia o estrechez de miras) pretenden relegar al noveno arte. 